\title{
Debate: Public audit, the Redmond review, and the use of public interest reports
}

\section{Pete Murphy \& Katarzyna Lakoma}

To cite this article: Pete Murphy \& Katarzyna Lakoma (2021) Debate: Public audit, the Redmond review, and the use of public interest reports, Public Money \& Management, 41:2, 150-151, DOI: 10.1080/09540962.2020.1821505

To link to this article: https://doi.org/10.1080/09540962.2020.1821505

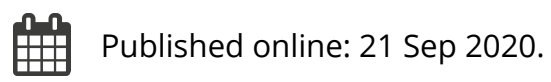

Submit your article to this journal $\sqsubset$

\section{Џ Article views: 44}

Q View related articles $\longleftarrow$

View Crossmark data ¿ 
Tollefson, J. (2018, January). China declared world's largest producer of scientific articles. Nature, 553(390). Retrieved from https://www.nature.com/articles/d41586-018-00927-4. van Helden, J., \& Argento, D. (2020). New development: Our hate-love relationship with publication metrics. Public Money \& Management, 40(2), 174-177. DOI: 10.1080/ 09540962.2019 .1682353 .
What are Altmetrics? https://www.altmetric.com/aboutaltmetrics/what-are-altmetrics/.

Taylor \& Francis Editor Resources-The Use of Metrics in Research Assessment. https://editorresources.tayloran dfrancis.com/peersupport/the-use-of-metrics-in-researchassessment/?utm_medium=email\&utm_source $=$ EmailStudio\&utm_campaign=JPA12797_3549730.

\section{Debate: Public audit, the Redmond review, and the use of public interest reports}

Pete Murphy and Katarzyna Lakoma

Nottingham Business School, Nottingham Trent University, UK

Public audit arrangements for local authorities in England are currently being subjected to a widescale independent review led by Sir Tony Redmond-a past president of CIPFA. This follows a series of recent government reviews into audit from Sir Kingman (2018) on the Financial Reporting Council, the Competition and Markets Authority's (2019) study of the statutory audit market and Sir Brydon (2019) on the quality and effectiveness of audit. It also reflects growing concerns about the arrangements for public audit, the implementation of the Local Audit and Accountability Act 2014 and the public assurance regime for local authorities in general (Murphy et al., 2019). Last year the NAO reported that 'qualified conclusions on arrangements to secure value for money locally are both unacceptably high and increasing. The proportion of local public bodies whose plans for keeping spending within budget are not fit-for-purpose, or who have significant weaknesses in their governance, is too high' (NAO, 2019, p. 8).

Appointed in July 2019, the Redmond review published a consultation document in September 2019 containing 43 questions, including specific questions about the use of public interest reports (PIRs). Since this consultation closed, the awareness of PIRs has spiked as a result of the publication of the first report to a principal council since the 2014 Act was implemented and the failure, despite repeated indications to the contrary, of another auditor to issue a PIR.

PIRs provide auditors with the power to report publicly on any matter that adversely influences a council's finances that may be of interest to the authority or to the general public. PIRs are part of the arrangements for value-for-money reporting and can be made at any time and must be copied to the secretary of state for local government. There are equivalents reports in Scotland and Wales, and New Zealand has provision for 'other matter' paragraphs in its annual audits under the Public Audit Act 2001. Among other things, these can review contract practices for probity, sensitive spending, or governance Issues.

A PIR was issued to Nottingham City Council in August 2020 under section 24, schedule 7 of the 2014 Act (Grant Thornton, 2020). It related to the governance and financial affairs of their Robin Hood Energy company established by the council in 2015 . There has been a small but regular number of reports on town and parish councils and parish meetings since the Act was implemented, but all previous principal council reports have issued under section 8 of the Audit Commission Act 1998 or earlier legislation.

PIRs were numerous and high profile in England prior to the implementation of corporate inspections and interventions. In 1985 there were 54 and, in 1986, there were 89-with later high-profile reports in the London boroughs of Westminster (1988) and Hammersmith \& Fulham (1989). There was another spate of reports around the time Best Value and Comprehensive Performance Assessments were introduced in 2002, but Redmond noted that PIRs 'seem to no longer be used' which 'is surprising given the increasingly high profile of commercial and other new arrangements entered into by some local authorities' (Redmond, 2019, p. 29). The latter is, of course, one of the issues with Nottingham City Council and it has also been part of a long-running saga at Northamptonshire County Council. In their fifth report to the secretary of state for local government in March 2020, Northamptonshire County Council stated:

After a lengthy period of deliberation, the Council's previous auditors have decided not to issue a Public Interest Report into the events leading up to the financial collapse of the organisation. We are disappointed by this decision. For the first local authority in a generation to effectively declare itself insolvent not to be the subject of such a report is certainly surprising given the subject matter of previous Public Interest Report... we believe there is a lot to learn from Northamptonshire (McArdle \& Roberts, 2020, p. 2.) 
The response from Nottingham City Council was immediate and comprehensive, with the leader of the council issuing a public apology and announcing that the council would accept and expedite the implementation of all 13 recommendations of the auditors. They have since announced the closure of the company and the sale of the company's customer book to British Gas.

So, if PIRs are so effective why are there so few? In their response to Redmond, the PSSA commented that auditors 'are leaning more towards making statutory recommendations as they perceive that they are quicker to process and receive appropriate publicity' although 'statutory recommendations are also used relatively infrequently' (PSAA, 2019, p. 31). ICAEW thought 'local public auditors and management believe that auditors' other powers, such as statutory recommendations, are more effective tools in raising and alerting stakeholders about issues of concern' (ICAEW, 2019, p. 28).

This was not the case in Northamptonshire County Council where the Best Value report (Caller, 2018) reveals that recommendations were featured in the 2016/17 and 2017/18 audit reports to no avail.

In Nottingham, the auditors having previously expressed concerns to senior officers and the audit committee, decided in October 2019 that it was appropriate for them to make formal recommendations to the council to draw attention to the level of risk faced and encourage it to take further action to manage those risks: 'We determined, however, that it was not in the public interest at that time for such consideration to be made public, and we therefore agreed with the council that it would treat our recommendations as if they were statutory recommendations with the exception of meeting the publicity requirements'. The auditors wrote to the council in December 2019 who considered it a private meeting of the council executive. However, the auditors did not receive a formal response. This also left the most important stakeholders-the council taxpayers and the customers of Robin Hood Energy-in ignorance about the security of their energy supply. It took the PIR to get any information and instant action.

In our view, PIRs and statutory recommendations are both useful parts of the public assurance and financial investigation portfolio, as are statutory interventions based on part 3 of the Local Government Act 1999
(Best Value inspections). There are circumstances where either or both can be effective, but neither are sufficient to cover all relevant circumstances. The NAO have given a great deal more prominence to both in their latest Code of Audit Practice (NAO, 2020) but, given past experience and the proliferation of commercial involvements and hybridized governance arrangements involving local authorities, we think they need revitalizing and a more fundamental review. We hope Sir Tony Redmond agrees.

\section{Disclosure statement}

No potential conflict of interest was reported by the author(s).

\section{References}

Brydon, D. (2019). Assess, assure and inform: Improving audit quality and effectiveness report of the independent review into the quality and effectiveness of audit. BEIS and TSO.

Caller, M. (2018). Northamptonshire County Council best value inspection. Available at https://www.gov.uk/ government/publications/northamptonshire-countycouncil-best-value-inspection

Competitions and Markets Authority. (2019). Statutory audit services market study. CMA.

Grant Thornton. (2020). Nottingham City Council Report in the Public Interest concerning the Council's governance arrangements for Robin Hood Energy Ltd. Available at https://www.nottinghamcity.gov.uk/media/2835756/ report-in-the-public-interest-rhe.pdf

ICEAW. (2019). Representation 128/19. https://www.icaew. com/-/media/corporate/files/technical/icaew-representati ons/2019/icaew-rep-128-19-redmond-review-on-lg-financi al-reporting-and-external-audit-in-england.ashx.

Kingman, J. (2018). Independent review of the Financial Reporting Council. BEIS and TSO.

McArdle, T., \& Roberts, B. (2020). Northamptonshire county council: Fifth commissioners' report. MHCLG and TSO.

Murphy, P., Ferry, L., Glennon, R., \& Greenhalgh, K. (2019). Public Service Accountability: Rekindling a Debate. Palgrave Macmillan.

NAO. (2019). Local audit reporting in England 2018.

NAO. (2020). Code of audit practice.

PSAA. (2019). Response to Sir Tony Redmond review. Available at https://www.psaa.co.uk/2020/01/news-release-response-tosir-tony-redmond-review/.

Redmond, T. (2019). Independent review into the arrangements in place to support the transparency and quality of local authority financial reporting and external audit in England. TSO. 